\title{
Kegiatan Perdagangan: Suatu Penjelasan Berdasarkan Teori Simbolis
}

\author{
Widya Nayati
}

Keywords: archaeology, trade, economy, theory, analogy

\section{How to Cite:}

Nayati, W. Kegiatan Perdagangan: Suatu Penjelasan Berdasarkan Teori Simbolis.

Berkala Arkeologi, 15(3), 96-104. https:// doi.org/10.30883/jba.v15i3.679

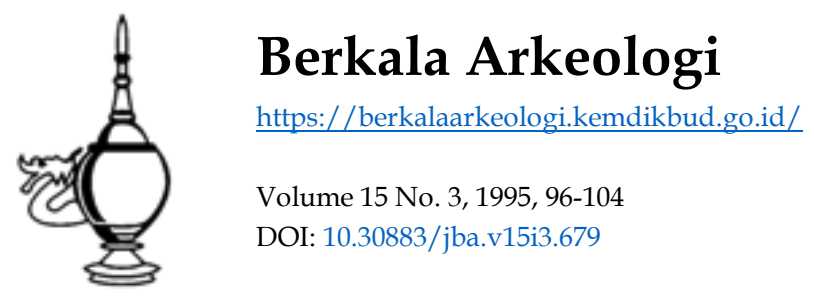

\section{(c) (i) (9)}

This work is licensed under a Creative Commons Attribution-NonCommercialShareAlike 4.0 International License. 


\title{
KEGIATAN PERDAGANGAN: SUATU PENJELASAN BERDASARKAN TEORI SIMBOLIS
}

\author{
Widya Nayati \\ (Jurusan Arkeologi FS-UGM)
}

Perdagangan merupakan suatu sistem yang tersusun dari berbagai komponen terkait satu dengan lainnya. Sistem ini sangat fleksibel cakupannya, baik cakupan waktu maupun cakupan wilayah. Satu sama lain dapat dilihat secara masing-masing komponen tetapi akan lebih jelas kalau dilihat secara global. Kespesifikan ini yang menjadikan sistem perdagangan mempunyai kesamaan dan perbedaan antara satu cakupan wilayah dengan lainnya, dengan waktu yang bervariasi. Hal ini karena dipengaruhi oleh berbagai faktor baik dari luar maupun dari dalam sistem itu sendiri. Perbedaan-kesamaan yang ada muncul antara lain karena adanya kegiatan politis-ekonomis-religius (Politic-economics and religious) yang akhirnya mempengaruhi perubahan manusia pendukungnya. Suatu rangkuman data secara arkeologi-kesejarahan akan digunakan dalam menganalisa kegiatan perdagangan di Indonesia dari dulu hingga kini.. Analisis dengan pendekatan teori simbol dicoba dijelaskan secara common sense (Geertz, 1983; Pryor, 1977) dengan harapan akan dapat mengetahui strategi perdagangan dan manusia. Selain itu, diharapkan hasil analisis dalam kegiatan perdagangan dapat di-pakai dalam menentukan strategi perdagangan masa kini dan yang akan datang.

Ada beberapa kendala yang menyebabkan penelitian arkeologi di Indonesia tentang perdagangan belum dapat mengungkap sistem perdagangan secara jelas. Faktor pertama, hingga kini belum dilakukan penelitian arkeologis yang bertujuan mengungkap kegiatan perdagangan. Interpretasi tentang kegiatan perdagangan di kepulauan Nusantara hanyalah merupakan akibat dari penelitian perkotaan, seperti yang dilakukan di Banten dan Kota Cina. Faktor kedua, adanya penelitian yang mengacu pada masa pembabakan periodisasi Arkeologi Indonesia (Prasejarah, Klasik, Islam, Kolonial) menjadikan tidak terfokusnya data yang berada di luar spesialisasi peneliti (Nayati, 1994). Selain itu, adanya penelitian yang bersifat sproradis serta tak berkesinambungan menjadikan hasil penelitian tidak lengkap. Akibatnya, baik penelitian perkotaan ataupun penelitian arkeologis lainnya, belum dapat dijelaskan secara berkesinambungan. Tambahan lagi, hasil penelitian tidak terpublikasi secara luas, ba-ik kepada arkeolog, ilmuawan lain serta masya-rakat umum. Akibatnya usaha pengungkapan ke- adaan masa lalu secara jelas menjadi sulit dilakukan. Faktor ke tiga, data arkeologi yang berkaitan dengan perdagangan sangat sulit ditemukan sehingga sulit diungkapnya kegiatan perdagangan itu sendiri. Kesulitan yang ada ialah, tidak diperolehnya bukti barang dagangan lokal di daerah pemproduksi dan daerah tujuan, karena barang komoditinya lebih banyak bersifat barang kebutuhan pokok (misalnya beras, cengkeh, mrica, tuak) dan barang yang tidak dapat bertahan lama (misalnya kain). Akibatnya, pola distribusi barang menjadi sangat sukar dibuktikan secara arkeologis, kecuali bila menemukan artefak keramik dan mata uang (Nayati,1994). Faktor keempat, interpretasi atas keramik (Asia dan Eropa) dan mata uang selalu mengarah pada kontak antara orang asing dengan lokal. Lebih lanjut dapat dikatakan bahwa keberadaan keramik Cina di suatu situs selalu mengarah pada interpretasi bahwa pedagang Cina adalah pembawa barang tersebut. Padahal, berdasarkan data kesejarah-an dapat diinterpretasikan bahwa belum tentu keramik Cina tersebut dibawa oleh pedagang Cina karena beberapa alasan. Pertama peda-gang Cina tidak terlalu berkonsentrasi pada perdagangan-keliling (peddling system) atau bertindak sebagai pedagang-pelaut (Nayati, 1994) Alasan kedua karena ditemukan keramik Cina pada daerah-daearh yang tidak menjadi daerah konsentrasi perdagangan Cina, seperti di daerah Maluku setelah abad 10. Salah satu kemungkinan adanya korelasi antara keramik Cina dengan pedagang Cina ialah karena adanya simbol yang selalu mengarah pada simbol Cina. Simboi tersebut selalu tertancap dalam pola pikir peneriti yang menemukan data keramik di situs penelitiannya.

Kendala tersebut di atas menjadikan penginterpretasian kegiatan perdagangan di Kepulauan Nusantara lebih banyak mengandalkan data kesejarahan (Nayati, 1994). Padahal data kesejarahan berjumlah relatif sedikit, hanya mencakup masa tertentu dan daerah tertentu saja. Selain itu. data yang ada hanya mencatat kegiatan orang asing, sehingga fokus yang dicatat tidak selalu sama, tergantung pada minat pencatat. Namun demikian, data tersebut dapat membantu menginterpretasi beberapa faktor yang ada pada kegiatan perdagangan, misalnya pola distribus barang, variasi barang dagangan, sistem penim- 
bangan dan mata uang (antara lihat:catatan Tome Pires, Joseph Banks, Alfonso Alboquerque, J.H. van Linshoten, H. Middleton, D. Borbosa, C de Houtman, J. Lancaster, dan Thomas Best). Lebih lanjut dapat pula diketahui beberapa aspek yang berhubungan dengan jaringan perdagangan di kepulauan Nusantara-Asia-Eropa.

Konsentrasi perdagangan di beberapa tempat di dunia berubah antara lain karena masuknya unsur kegiatan politis dan religius pada kegiatan ekonomis. Perkembangan jalur perdagangan, baik jalur darat dan laut, dari Mideterania ke daerah Asia Barat dilakukan karena keingian mendapatkan rempah-rempah dari Yaman, juga karena meningkatnya kegiatan agama Katholik, Protestan, Yahudi, dan Islam (Curtin,1984; Hourani, 1991). Jalur perdagangan ke Amerika merupakan suatu kegiatan discovery yang ditunjang oleh pemerintah, dan untuk mendapatkan komodit emas (Curtin, 1984; Cameron, 1989; Braudel,1985). Kegiatan yang bersifat politis-ekonomis-religious juga merupakan penyebab perubahan konsentrasi perdagangan yang ada di Asia, khususnya di Kepulauan Nusantara hingga abad 18, seperti yang dilakukan oleh orang-orang Asia barat, Cina, Portugis, Spanyol, Inggris dan Belanda untuk menguasai komoditi dan daerah (Cortesao, 1944; Meilink-Roelofsz, 1962; Israel, 1989; Kathirithamby-Wells, 1987; Reid,1992; van Leur, 1955; Nayati,1994a,b). Secara jelas dapat diketahui bahwa adanya jaringan perdagangan tersebut menyebabkan perubahan pada kehidupan sosial-budaya masyarakat. Misalnya ditemukannya data arkeologis di Indonesia, baik data bangunan keagamaan maupun budaya material.

Perubahan perdagangan internasional di kepulauan Nusantara secara jelas dapat dilihat perubahannya (Nayati,1994). Masuknya pedagang Asia ke bagian barat kepulauan Nusantara merupakan salah satu pemicu ramainya daerah perdagangan di Nusantara. Menurunnya kekuasaan Sriwijaya menjadikan perdagangan di Nusantara semakin meluas dan bebas dilakukan oleh meminat. Kontak antara pedagang-perantara-penduduk lokal menjadi semakin intensif, sehingga tanpa disadari terjadi pengenalan sistem perdagangan lokal dengan perdagangan internasional. Berdasarkan data arkeologis dapat diketahui bahwa mata uang dirham, kepeng, ma, dan koin sandalwood telah ditemukan di beberapa situs perdagangan di Asia, khususnya di Kepulauan Nusantara (Wicks, 1992). Selain itu, data kesejarahan membantu mengungkapkan sistem penakaran barang dagangan di Maluku juga dikenal di Jawa, Sumatra dan Malaka, seperti Bahar, pikul dan gantang (Nayati, 1994)
Adanya pemukiman pedagang Asia, khususnya di kepulauan Indonesia menjadikan jalur perdagangan internasional menjadi lebih intensif. Nisan (Leran, Barus), mata uang 'Ma', mata uang kepeng, Prasasti dengan huruf Tamil (Barus) (Drakard,1989; Nurhakim,1989), serta keramik, merupakan sebagian bukti adanya pemukiman pedagang asing yang menetap di wilayah kepulauan Nusantara. Tulisan orang Eropa juga mencatat keberadaan pedagang dan pemukiman asing di beberapa wilayah di Kepulauan Nusantara seperti di Aceh, Banten, Barus, pantai timur Sumatra, pantai utara Jawa, Nusa Tenggara, dan Maluku (Eerste, 1664; Foster, 1905, 1934, 1943 Cortesao, 1944; van Leur, 1955; Meilink-Roelofsz. 1962; Nayati, 1994)

Masuknya pedagang Eropa dalam pasar rempah di Asia Tenggara telah menggeser pola jaringan perdagangan lokal di Indonesia (Nayati, 1994). Pedagang Eropa mempunyai tekanan minat yang berbeda dengan pedagang Asia dan mempunyai cara berbeda dalam pencapaian usahanya. Sebagai contoh, dapat diinterpretasikan bahwa pedagang Cina keluar dari usaha mengumpulkan rempah-rempah Maluku karena mulai banyaknya perdagang di kawasan ini (Asia Eropa dan Nusantara), dan mengalihkan usahanya sebagai pengumpul rempah-rempah di pelabuhan entrepot serta mengalihkan usahanya mengumpulkan kayu cendana di wilayah Nusa Tenggara (Nayati, 1994). Selain itu, pedagang Belanda tercatat berusaha mendapatkan rempah, dengan melakukan tekanan politis seperti yang dilakukan pada Sultan Banten, Aceh, Ternate, dan Tidore. Usaha Belanda tersebut merupakan usaha untuk mengalahkan pedagang Inggris yang mampu berkolusi dengan para Sultan ter-sebut di atas, dan juga para pedagang Nusantara (Nayati,1994). Hanya saja, ketika Inggris tetap mampu mendapatkan rempah dari daerah monopoli Belanda di Maluku, maka Belanda melakukan politik ekonomi dengan membakar pusat perdagangan Inggris. Politik tersebut dilakukan oleh Belanda di wilayah Kepulauan Nusantara, seperti yang dilakukan di Banten, Jambi, Indrapura, Pariaman, Tiku, dan Aceh (KathirithambyWells, 1989; Ptak, ).

Kegiatan politis-ekonomis seperti tersebut di atas, dilakukan pula oleh pedagang dan penguasa Nusantara pada masa lalu. Simbol kekuasaan politis-religius di bidang perdagangan pada perkembangannya terlihat beralih pengontrol, dari penguasa pada masa sebelum abad 18 ke penjual/pengusaha pada masa sekarang.

Pada masa lalu, kontrol yang bersifat politis-religius dilakukan oleh penguasa untuk mencegah masuknya pesaing dan monopoli perdaga- 
ngan. Sebagai contoh, Sultan Aceh dan Pangli-ma di daerah kekuasaannya menolak berdagang dengan pedagang Portugis dan Belanda (Kathirithamby-Wells,1989; Nayati, 1994a). Cara yang digunakan selain dengan mencegah pedagang non-muslim berdagang di daerahnya, juga dilakukan dengan mengadakan ijin berdagang yang harus diminta keabsahannya dari Sultan Aceh. Peraturan yang dicanangkan oleh Sultan Aceh menunjukkan bahwa agama dapat dipakai untuk membatasi kegiatan persaingan perdagangan. Apabila ditilik dari faktor ekonomi, sebetulnya Sultan Aceh melakukan politik tersebut dalam usahanya mengumpulkan mrica sebanyak-banyaknya serta mengurangi saingan dagang sehingga dapat mengexport mrica ke Asia Barat. Secara ekonomis, dapat diduga bahwa keuntungan eksport mrica ke pasar internasional tersebut lebih banyak daripada keuntungan perdagangan di wilayah kerajaan Aceh. Keputusan Sultan Aceh tersebut diduga karena sudah adanya pem-beli yang pasti di pasar internasional serta kemungkinan karena adanya adanya backing dari kerajaan Turki. Lebih jauh dapat diinterpretasikan bahwa agama dapat dipakai sebagai simbol kekuasaan terutama dalam menekan persaingan demi keuntungan secara ekonomis bagi penguasa. Selain itu, agama dapat dipakai sebagai simbol kerjasama dalam kegiatan ekonomis seperti yang dilakukan Kerajaan Aceh dengan kerajaan Turki.

Masuknya pedagang Asia dan Eropa ke kepulauan Nusantara merubah jalur konsentrasi perdagangan dan merubah kehidupan sosial masyarakat. Kegiatan pedagang Eropa sejak awal abad 16 tersebut telah menggeser pola distribusi barang lokal dan barang dari luar Nusantara, terutama barang Asia. Berdasarkan data sejarah diketahui bahwa kain katun India disukai oleh penduduk Nusantara dan merupakan barang yang tinggi harganya (Cortesao, 1944). Kain katun Gujarat ke Maluku menjadikan kain Jawa dan Nusa Tenggara menjadi turun nilainya (Reid, 1988), tidak saja dalam harga tetapi juga nilai sosialnya. Kain Gujarat menjadi salah satu sim-bol status sosial golongan atas karena harga ba-rang tersebut hanya dapat dijangkau dengan se-jumlah uang/barang komoditi. Kain tersebut dipa-kai juga sebagai salah satu hadiah dari pedagang Asia barat pada penguasa daerah. Keadaan ter-sebut dipahami oleh pedagang Inggris, sehingga berusaha mendapatkan kain India untuk ditukar dengan dengan rempah-rempah (Foster, 1934, 1940, 1943; Chaudhuri, 1985, 1987) Kebutuhan akan kain katun dapat tercukupi dengan adanya kontak dan pemukiman Inggris di India (Chaudhudri, 1985, 1987) Kemampuan tersebut menja- dikan pedagang Belanda berusaha mendapatkan kain India sebanyak mungkin, untuk menyaingi pedagang Inggris dalam mengumpulkan rempah. Dapat disimpulkan bahwa pada awal abad 17, di Nusantara terdapat banyak kain katun India sebagai barang penukar rempah selain menggunakan koin. Akibatnya, dapat diduga terjadi pergeseran pola konsumtif penduduk lokal dari kain lokal ke kain katun India. Selain itu, diduga harga barang tersebut turun harganya dibandingkan harga pada sebelum abad 17 . Tentunya, dapat ditarik kesimpulan bahwa perubahan konsumtif kain, juga diikuti dengan perubahan pola kehidupan mereka. Memang penarikan kesimpulan tersebut hanya berdasarkan data kesejarahan, sehingga perlu ada penelitian arkeologis yang dapa: membuktikannya.

Perubahan kehidupan sosial antara lain dilakukan dalam bentuk kebebasan memilih barang. Pola konsumsi barang menjadi bergeser antara lain karena variasi dan jenis 'baru'. Sebagai contoh, diketahui bahwa pedagang Asia Barat membawa berbagai jenis kain katun dengan berbagai nama, warna dan ukuran (van Leur, 1955; Meilink-Roelofsz, 1962; Chaudhuri,1985), sedangkan kain sutera dibawa dari China. Selain itu, data orang Eropa menyebutkan bahwa mereka berusaha mendapatkan kain India sebanyak mungkin karena dapat penduduk Nusantara sangat menyukai barang tersebut. Dari data ini dapat diinterpretasikan bahwa penduduk Nusantara dapat memilih berbagai jenis kain yaitu kain ka-tun lokal, kain Gujarat/India, serta kain silk China (Cortesao, 1944; Meilink-Roelofs, 1962; Chaudhuri,1985; Reid,1988). Kebebasan memilih barang merupakan simbol kebebasan memenuhi kebutuhan pribadi sesuai dengan kemampuan dan kebutuhan. Lebih lanjut dapat pula diinterpretasikan bahwa adanya berbagai pilihan menjadikan perubahan pola konsumtif dari yang hanya kain lokal berubah ke non lokal. Hanya saja penduduk lokal masih mengkonsumsi kain lokal, dengan bukti kesejarahan (van Leur,1955; Meilink-Roelofsz, 1962, Reid,1988) bahwa pedagang Nusantara membawa kain katun Jawa dan Nusa Tenggara hingga Sumatra dan Maluku. Kepemilikan kain, lokal dan non lokal, digunakan sebagai kebutuhan pokok dan juga sebagai kebutuhan rohani, misalnya sebagai simbol status sosial.

Pergeseran nilai konsumtif penduduk lokal dapat dikatakan sebagai salah satu gejala perubahan persepsi nilai dan perubahan fungsi antara pembawa dan pembeli. Barang yang dibawa pedagang Nusantara, Asia dan Eropa kemungkinan besar diartikan sebagai barang yang tinggi harganya, secara instrinsik maupun secara moral. Perlakuan seperti itu disebabkan karena ke- 
langkaan barang, asal barang serta harga barang. Akibatnya, kepemilikan barang tertentu dapat menaikkan status golongan seseorang. Selain itu, ada kemungkinan lain bahwa barang tertentu yang seharusnya difungsikan sebagai barang keseharian dapat berubah menjadi barang ideo dan sosioteknik. Keadaan semacam dapat pula ditemui pada masa sekarang, misalnya piring keramik kuna sebagai bagaian dari kegiatan upacara, 'pecut' berubah fungsi dari alat pemecut kuda/kerbau menjadi hiasan rumah, atau 'klonthongan' sapi/kerbau menjadi bel rumah.

Kegiatan perdagangan di Kepulauan Nusantara dilakukan secara bebas tetapi dapat dijelaskan bahwa kegiatan tersebut terkordinir dengan baik. Pada kegiatan ini, faktor sosial, religi dan politis berperan untuk mendukung kegiatan yang bersifat ekonomis. Peran pejabat negara (kerajaan) sangat penting, seperti ditandai dengan adanya kontak/kunjungan ketua pedagang asing ke pejabat kerajaan dan raja/sultan serta adanya kontrol jumlah dagangan yang dibeli oleh pedagang asing. Pemberian hadiah dari pedagang asing ke penguasa dilakukan pada saat kunjungan tersebut, seperti terungkap pada data kesejarahan. Pemberian hadiah dilakukan oleh pedagang Portugis, Belanda, Inggris kepada penguasa di Aceh, Banten, Tidore, Ternate dan juga panglima di Tiku dan Aceh (Nayati, 1994). Barang yang diberikan biasanya berupa barang dagangan yang dibawa serta barang spesial dari negara asal pedagang, hanya saja, secara arkeologis, kegiatan tersebut belum dapat tersirat dari data arkeologis, walaupun beberapa artefak (yang dianggap langka, berjumlah relatif; sedikit, berkualitas tinggi serta ditemukan di kawasan yang berorientasi pada status sosial kelas atas (misalnya kraton)), dapat dipakai untuk menjelaskan kegiatan pemberian hadiah tersebut. Berdasarkan data kesejarahan dapat ditarik kesimpulan proses kegiatan perdagangan masa lalu, terutama dengan orang asing. Proses kegiatan jual beli bagi orang asing dapat dimulai setelah pedagang asing mendapatkan ijin berdagang dari penguasa tertinggi dan setelah penguasa memilih-membeli barang-barang yang dibawa pedagang asing, seperti yang terjadi di Banten.

Adanya pemberian hadiah merupakan bagian dari usaha untuk mendapatkan rasa aman bagi pemberi, sebagai alat untuk mempererat hubungan perdagangan secara langsung, dan juga untuk mempererat hubungan sosial (Lewis,1976). Pada masa modem, peran penguasa pemerintahan disimbolkan dengan adanya pejabat di bidang perekonomian, perpajakan, Bulog, Kadin dan asosiasi lainya yang dijalankan berdasarkan aturan yang tertulis. Keberadaan grup tersebut merupakan salah satu usaha mengontrol perdagangan bebas yang ada. Malahan kerjasama perdagangan internasional bertambah hidup dengan adanya perjanjian-perjanjian perdagangan antara satu negara dengan negara lainnya. Hal semacam bukanlah hal yang iśtimewa bagi kegiatan perdagangan, karena perjanjian antara dua negara dilakukan juga antara penguasa kerajaan di kepulauan Nusantara misalnya Sultan Aceh (dan Panglimanya), Sultan Banten, Sultan Tidore, Ternate dengan pedagang Thailand, Cina, Turki, Spanyol, Portugis, Inggris, dan Belanda.

Hadiah dan kesempatan membeli bagi pa-ra pejabat kerajaan dapat dipakai sebagai simbol kekuasaan dan status sosial. Di lain pihak, si pemberi hadiah menggarapkan suatu imbalan yang sepadan (Lewis, 1976) Hanya saja, harapan pemberi dan penerima hadiah terkadang berbeda, dan biasanya pada pemberian hadiah tersebut, penerima akan mendapatkan keuntungan yang lebih besar dari pemberi (Lewis, 1976). Hanya saja, usaha untuk mendapatkan 'ijin' berdagang selalu menjadi hal yang penting bagi penjual, oleh karena itu, usaha untuk memperkenalkan diri pada penguasa serta berlaku baik pada penguasa selalu dilakukan dengan memberikan fasilitas yang baik serta memberikan hadiah bagi penguasa. Pemberian tersebut merupakan hal yang menguntungkan bagi penguasa karena mendapatkan simbol status sosial yang istimewa dan hanya dimiliki oleh orang tertentu saja.

Pemberian hadiah ternyata juga dilakukan oleh penjual kepada konsumen, hanya saja dengan cara dan jumlah yang berbeda dengan hadiah bagi penguasa. Pemberian yang dilakukan oleh penjual ternyata dapat memberikan keuntungan, terutama secara moral bagi para pembeli. Hadiah yang diberikan dapat berupa penambahan jumlah volume oleh penjual, terutama penjual tradisional di pasar, misalnya dengan menambah dalam volume kecil pada beras, kacang, cabe, menjual dengan cara 'welasan', pemberian komisi, hadiah tambahan (kalender, beli dua dapat tiga, dsb) serta discount.

Strategi perdagangan yang bersifat politisekonomis-religius dilakukan juga pada kegiatan perdagangan pada wilayah dan masa yang berlainan. Kegiatan politis-ekonomis-religius dapat dilihat dari pola kota serta kemunculan kota seperti yang tercermin pada letak pasar (di Paseban dan Pecinan di Banten) (Nayati.994), adanya pasar di pelabuhan entrepot Gresik, adanya pengelompokan pernukiman berdasarkan agama serta adanya pembentukan pemukiman ekslusif (misalnya Batavia, Ambon, Banda). Tambahan lagi letak pasar besar suatu pusat pemerintahan selalu disimbolkan dengan letaknya yang berki-sar 
antara utara dan timur-laut alun-alun utara suatu kerajaan. Kesemuanya dapat dilihat seba-gai simbol kekuasaan ekonomis-religious dan po-litis penguasa setempat. Sebagai contoh, adanya pengelompokan pemukiman berdasarkan ras, agama, asal dan profesi dipakai oleh penguasa untuk mengontrol pengumpulan komoditi. Kegiatan ini dilakukan berkenaan dengan jumlah pajak yang harus dibayar. Pembentukan pemukiman baru oleh pedagang asing, terutama Belanda, merupakan salah satu upaya penguatan status superior dari para pesaingnya. Sebagai contoh, kota Ambon dan Banda dibangun sebagai daerah pengumpul rempah di Maluku. Dapat diinterpretasikan bahwa pengiriman orang Cina dari Batavia ke daerah Maluku merupakan salah satu cara Belanda untuk menjadikan daerah tersebut sebagai daerah yang layak dihuni. Dapat dikatakan, orang Cina-lah yang menjadikan daerah Batavia menjadi ramai. Selain itu, pedagang Cina merupakan pedagang yang dianggap mudah bersatu seperti yang dilakukan pedagang $\mathrm{Ci}$ na yang membawakan mrica dari daerah Sumatra ke Batavia. Juga, pedagang Cina terkenal sebagai pemasok barang yang baik seperti yang dilakukan terhadap pedagang Portugis di Malaka, pedagang Inggris di Banten. Kemampuan Belanda menjadikan Ambon dan Banda sebagai daerah pengumpul komoditi Maluku, dapat dikatakan sebagai simbol kemenangan Belanda dalam menguasai rempah Maluku, dan juga sebagai sim-bol keunggulan yang mengalahkan Inggris yang 'menjadikan' kota Makasar menjadi kota perdagangan yang menyaingi kegiatan perdagangan monopoli Belanda.

Kegiatan religius, yang membatasi ruang gerak pesaing, tersimbolkan pada beberapa objek perdagangan di masa sekarang. Misalnya, makanan dengan tulisan halal, adanya nama-nama barang berkonotasi Islam, lambang yang menggunakan tanda ke-Islaman, merupakan salah satu simbol penawaran dagangan yang berusaha menaikkan jumlah konsumen yang mayoritas Islam dan juga membatasi gerak pesaingnya. Dalam hal ini, politik ekonomis yang bersifat religius dipakai demi keuntungan pengusaha. Usaha tersebut bertambah berhasil karena dilakukan pada saat kehidupan dan kebangkitan agama Islam mulai terjadi di Indonesia. Dapat disimpulkan bahwa kehidupan pergeser antara lain karena perkembangan teknologi. hanya saja, faktor religius berperan dalam mengendalikan pergeseran sosial yang berjalan, terutama dengan mempertanyakan ke'halal'an barang yang dibelidimakan dan dikonsumsi.

Sistem penawaran terbuka dari dulu hingga sekarang dilakukan oleh pedagang untuk mena-rik pembeli. Cara-cara penawaran dapat diinterpretasikan dari simbol-simbol yang digunakan. Pedagang tradisonal di pasar meletakkan barang dagangannya secara terbuka dan kadang-kadang dengan menawarkan dagangannya pada pembeli, seperti yang terlihat pada pedagang sayuran di pasar-pasar. Keadaan seperti itu dilakukan pula oleh pedagang sayuran dan penjual barang second hand di luar Indonesia. Cara lain dalam menawarkan barang yaitu dengan cara menggantungkan barang dagangannya di kios dan toko, sehingga menarik perhatian pembeli. Cara pemajangan barang ini tidak saja dilakukan oleh pemilik modal kecil tetapi juga oleh pemodal besar seperti disimbolkan dengan adanya etalase dan hiasan-hiasan pada ruang jual pertokoan masa kini. Penawaran di toko-toko dilakukan tidak secara jelas, karena barang yang dijajakan dipakai sebagai penghias ruangan toko. Cara-cara penawaran barang semacam itu dapat dikatakan sebagai hal yang mendunia dan sepanjang ma-sa, tidak saja dilakukan oleh pedagang Indo-nesia, tetapi juga pada pedagang di luar Indo-nesia, baik masa sekarang maupun pada masa yang lalu.

Usaha mendapatkan keuntungan sebanyak mungkin dilakukan dengan berbagai cara oleh penjual maupun pembeli. Salah satu bukti usaha mendapatkan keuntungan bagi penjual barang diperoleh dari data sejarah menyebutkan bahwa pedagang Inggris kecewa dengan cara pedagang Tiku/Pariaman yang menjual mrica basah dan juga mrica yang dicampur dengan kerikil (Foster, 1934, 1940, 1943). Selain itu, nilai gantang dan bahar berbeda antara satu lokasi dengan lainnya, misalnya 1 bahar mrica di Pidie sama dengan Pedir dan Pasai, tetapi lebih rendah dari Malaka dan Maluku (Cortesao, 1944; Meilink-Roelofsz, 1962). Cara lain mendapat keuntungan ialah dengan menimbang secara tidak sempurna seperti yang ditunjukkan oleh gambar pedagang Cina dengan timbangannya. Usaha pencurangan penjual tersebut tidak saja dilakukan oleh orang Nusantara, tetapi juga oleh penjual dari daerah lain dan pada masa yang kemudian. Sebagai bukti arkeologis dapat dibuktikan bahwa volume botol dan tulisan angka pada cap pada botol kuna yang berasal dari Eropa, selalu tidak sama, baik pada botol berukuran setengah liter maupun pada botol berukuran satu liter (Nayati, 1988). Pada masa sekarang, masih sering ditemukan ketidak cocokan jumlah ukuran berat antara satu toko dengan toko yang lain atau antara satu pedagang dengan pedagang yang lain. Hanya saja, data arkeologis tentang gantang, bahar, pikul hingga kini belum diperoleh secara jelas. Perlu diinformasikan bahwa anaktimbangan ditemukan di Trowulan 
Jual beli dengan sistem barter juga dilakukan seperti terlihat pada data kesejarahan. Kegiatan perdagangan yang mengacu pada sistem barter hingga kini masih juga ditemukan. Kegiatan barter disebut sebagai kegiatan pemindahan (transfer) bukan pertukaran (exchange) karena pada proses barter ini pemindahan barang atau jasa dilakukan dalam keadaan tidak seimbang, berbeda dalam proses perdagangan (Pryor, 1977) Kegiatan barter ini dapat dilakukan di pasar dan di luar pasar, terutama di pedesaan dan perkampungan. Sedang pengontrol harga, biasanya terletak pada pemilik barang, bukan pada penawar pertama. Pada kegiatan barter tradisional, status sosial pelaku pada golongan menengah bawah, terutama disimbolkan dengan letak kegiatan yaitu pasar dan di lingkungan pernukiman. Sering kali, pelaku barter dapat disimbolkan sebagai orang dari status sosial rendah, karena tidak mempunyai uang untuk mendapatkan sesuatu barang. terutama bahan makanan pokok. Anggapan tersebut tidak seratus persen benar, karena bila kegiatan barter dilakukan antara pedagang dengan pedagang yang barang dagangannya masih tersisa, maka status sosial keduanya menjadi tak terlihat secara jelas

Perdagangan barter meluas penggunaannya dan berkembang arti dan ruang lingkupnya. Saat ini dikenal adanya sistem barter yang dilakukan oleh masyarakat modern-non tradisional. Sistem barter dijalankan bukan lagi merupakan pertukaran barang dengan barang, tetapi anrtara barang dengan kepercayaan. Selain itu, kegiatan barter ini dilakukan antara 'pemilik' tak langsung (dalam hal ini petugas toko/kasir) dengan pemilik kepercayaan yang disimbolkan dengan credit card. Credit card dipakai luas karena kepraktisannya, baik ukurannya, jangkauannya pada golongan menengah atas, serta dapat menang-gulangi copet, tidak membawa uang dalam jum-lah besar dan mudahnya kegiatan pengontrolan keuangan terutama dengan adanya laporan ke-uangan dari Bank. Pengontrol 'harga' terletak pa-da pemilik credit card. oleh karena itu maka ke-pemilikan credit card menjadikan simbol tersen-diri bagi perniliknya, karena secara luas diketahui bahwa untuk mendapatkan credit card diperlukan sejumlah agunan uang yang cukup besar ditambah surat referensi dari orang 'kaya' dan terpandang. Akibatnya, kepemilikan credit card dapat menjadi simbol status sosial golongan atas bagi pemiliknya. Dapat juga dikatakan bahwa status sosial yang tinggi disimbolkan pula dengan nilai kepraktisan yang diberikan oleh credit card, yaitu pada kegiatan perdagangan kelas menengah ke atas saja. Adanya status sosial yang tinggi seperti ini sering menjadjkan kerugian pada pihak pemilik barang, karena apabila kepercayaan yang diberikan disalah gunakan oleh pemilik credit card. Hal yang berbeda pada sistem barter tra-disonal, karena penipuan tidak terjadi dan pemilik barang selalu untung.

Kegiatan barter tradisional dan non-tradisional tidak dapat digabungkan karena dua alasan. Pertama, pelaku pedagangan tradisonal tidak dapat menerima credit card dan cara administrasi yang memerlukan kemampuan tulis-menulis. Dan kedua, yang merupakan kelanjutan dari alasan pertama, yaitu karena status sosial yang berbeda diantara keduanya menjadikan gap yang tak terhubungkan, sehingga perbedaan status ini ditunjukkan dengan tulis menulis. Selain itu, perbedaan ini ditandai pula dengan sistem barter yang berbeda baik sistem maupun pelaku pela-ku. Kegiatan barter tradisional dilakukan karena pertukaran barang dengan barang sedangkaan yang kedua berdasarkan barang dengan kepercayaan yang disimbolkan dengan credit card. Selain itu barang yang ditukarkan merupakan barang dengan jumlah nominal yang besar.

Strategi perdagangan masa lalu ternyata masih dapat dilihat kelanjutan dan kesamaannya pada masa sekarang, baik oleh pedagang kecil, besar, tradisional, nasional dan intemasional Gejala yang ada di Yogyakarta sebagai contohnya, MacDonald-yang mempunyai distribusi internasional-membuka cabangnya setelah melihat saingannya: Pizza Hut sukses menandingi Kentucky and California Fried Chicken. Dua terakhir inipun terlihat dapat pula menjaring konsumen-nya untuk tidak datang ke Ayam Mbok Berek. Salah satu strateginya ialah penempatan lokasi restoran di ujung jalan menuju ke Ayam Mbok Berek. Daérah tersebut merupakan di jalan yang ramai, dekat dengan lingkungan kampus serta terjangkau kendaraan umum. Kentucky dan Ca-lifornia Fried Chicken memilih lokasi Jalan Ma-lioboromenjaring konsumen (domestik dan luar negeri) yang lelah berbelanja di sepanjang Ma-lioboro. MacDonald dengan 'Menu satu, Menu dua, tiga dan empat' bersaing pula di Malioboro Mall-tempat kongkow-kongkow $A B G$ Yogya. Strategi MacDonald lainnya ialah bekerja sama dengan Radio swasta Niaga di Yogya, dengan memberi hadiah makan gratis bagi para penja-wab quiz secara benar. Strategi menjaring pang-sa pasar benar-benar diperhitungkan demi terca-painya keuntungan sebanyak-banyaknya, satu gejala yang juga dilakukan oleh para pedagang pada masa lalu juga. Suatu perdagangan bebas yang terkordinir dengan menggunakan suatu dis-tribusi perdagangan dengan memanfaatkan jalur strategis, baik jalur jalan maupun jalur komunikasi. Keduanya dipadu untuk menjaring keun- 
tungan dengan iming-iming 'simbol status sosial terutama untuk anak muda.

Adanya komunikasi yang lancar serta teknologi canggih menjadikan meningkatnya kebutuhan seseorang, baik rohani dan jasmani. Temuan baru baik yang bersifat teknologis maupun konsumtif menjadi semakin meningkat. Akibatnya, persaingan antara hasil produksi lama dengan baru atau antara barang jenis $A$ dengan $B$, atau barang merek $X$ dengan $Y$ semakin tinggi. Akibatnya, cara penawaran yang seefektif dan sekreatif mungkin perlu dilakukan demi tercapainya keuntungan. Hal ini dimungkinkan dengan adanya alat komunikasi canggih yang ada sekarang ini. Seperti yang dilakukan iklan rokok dengan 'how low can you go' bersaing dengan Koboi Amerika, atau kemewahan Inggris dengan wama merahnya Dunhill.

Kreativitasan membuat iklan temyata dapat membantu mengungkap perkembangan kebahasaan suatu bangsa pada suatu masa. Sebagai contoh, nama-nama kain India, seperti sannoes, taffetas, dan dorcas (Chaudhuri, 1985) mungkin sudah dikenal oleh masyarakat Nusantara. Nama-nama tersebut mungkin berubah penyebutannya, seperti halnya catatan orang Eropa. Data semacam dimungkinkan untuk menginterpretasi waktu dan asal pedagang. Demikian pula pada masa kini, dapat diketahui bahwa 'rasa' menjadi berkembang, tidak saja rasa manis, asin, pahit, tetapi ada juga 'rasa ramai', 'rasanya eem', 'rasa nya wah', rasanya seperti...apa ya.... dan 'rasa semriwing'. Kata-kata tersebut tidak dikenal pada sepuluh tahun yang lalu. Terbukti bahwa bertambahnya jumlah barang baru diikuti oleh kreativisan dalam penawaran barang, dan diikuti pula oleh perkembangan kosa kata suatu bahasa. Kreativasan tersebut kadang sering dipakai sebagai penghibur dan joke, yaitu dengan menyelewengkan dan menggabungkan beberapa iklan menjadi satu, seperti: 'yang aku mau .... mau .... (silahkan diisi semau Anda)'.

Pada kenyataannya, simbol-simbol suatu jenis barang terlihat pada sistem penawaran, baik barang maupun jasa. Kalimat: 'tempatnya luas, papa-mama-pembantu ...' selalu diartikan dengan Toyota Kijang, 'Buka mulutnya dong', 'santai belum santai' untuk coklat Silver Queen, 'Just do it'. 'Oke', dan pada kenyataannya, 'geng-sinya dong' berkembang pada masa sekarang. Tentunya, 'iklan ini dipersembahkan oleh ...' merupakan simbol kemurahan hati, kemurahan harga iklan, dan kerja sama. Simbol-simbol yang dimunculkan oleh satu dua orang/grup terbukti menggeser dan mengembangkan kosa kata suatu bahasa. Mungkin kata-kata tersebut bila digabung dapat pula untuk menginterpretasikan 'gaya' masa kini yang 'Just do it, buka mulut, santai dan gengsi.

Lembaga konsumen dirasa perlu untuk menjembatani kebutuhan, kewajiban dan hak produsen dan konsumen. Munculnya barang baru dengan cara penawaran yang baru dan bagus menjadikan pembeli lebih bebas memilih barang yang dibutuhkan, baik kebutuhan pokok maupun bukan pokok. Kebebasan memilih ini tidak saja pada berdasarkan rasa, wama, kemasan dan harga yang bersaing tetapi juga pada lokasi beli, kenyamanan tempat membeli, keramahtamahan penjual, serta tersedianya fasilitas kemudahan lainnya, yang kesemuanya lebih cenderung mengacu pada kebutuhan rohani terutama masalah status sosial. Akibatnya, kadang-kadang dorongan membeli tanpa mempertimbangkan kebutuh-an atas barang tersebut sering dilakukan konsu-men. Pembelian dilakukan karena cara peletak-kan barang, cara pembungkusan, warna dan juga karena iklan yang menggebu. Di lain pihak, produsen dan penjual sering tidak memperhatikan kerugian atas barang yang dibeli konsumen, baik atas takaran yang tidak tepat dan sama, barang kadaluwarso, dan keselamatan konsumen. Untuk itu, perlu ditekankan dan dijelaskan lagi hak dan kewajiban konsumen dan produsen. Lembaga konsumen dirasa merupakan lembaga yang cocok untuk hal ini.

Namun demikian, diantara gencarnya iklan, sistem penawaran secara tradisional tetap dilakukan juga. Perlakuan sistem tersebut berkenaan karena sistem tradisional masih dibutuhkan oleh masyarakat yang majemuk. Kemajuan teknologi dan peradapan tidak dapat meninggalkan dan melupakan hal-hal yang masih tradisional, yang berbau masyarakat golongan menengah ke bawah. Nikmatnya hamburger, pizza, spagetti, steak daging import kadang membosankan dan ternyata dapat ditawarkan dengan tempe goreng, tempe bacem, SGPC, wedang ronde, bakmi tiktok, dan sate murahan di pinggir jalan.

Terima kasih kepada Dr. Sumijati As, Dra. Inajati Adrisijanti, Drs. Tjahjono Prasodjo \& Drs. J. Susetyo atas input yang diberikan sehingga tulisan ini dapat tersaji.

\section{KEPUSTAKAAN}

Braudel, Fernand. 1985. (Trans by Sian Reynolds) Civilization and Capitalism 15th-18th Century: The Perpective of the World, London, Fontana.

Chaudhuri,K.N.,1985, Trade and Civilisation in the Indian Ocean: an Economic History 
from the Rise of Islam to 1750, Cambridge, Cambridge University Press.

Chaudhuri, K.N.,1978, The Trading World of Asia and the English East India Company, Cambridge, Cambridge University Press.

Cortesao, A., 1944. (tran.), The Suma Oriental of Tome Pires and Account of the East, from the Red Sea to Japan, Written in Malacca and India in 1511-1515 London The Hakluyt Society

Curtin,Philip D.,1984.Cross-Cultural Trade in World History, Cambridge:Cambridge University Press.

Davis, John.,1992, Exchange, Minneapolis, University of Minneapolis Press.

Drakard,Jane.,1987. An Indian Ocean Port: Sources for the Earlier History of Barus, Archipel, 37, pp. 53-82.

Eerste Voyagie naer de oost-Indien onder Cornelis Houtman, in I Commelin (ed.), 1624. Begin ende Voortgangh van de Vereenighde Neer-landsche Geoctroveerde Oost-Indische Companie, 't Eerste Dell, Amsterdam.

Foster,Sir William., 1934. The Voyages of Sir James Lancaster to Brazil and the East Indies 1591-1603, London, Hakluyt Society.

Foster, sir William:, 1940, The Voyage of Thomas Best to the East indies 1612-1614, London, Hakluyt.

Foster,Sir William.,1943.The Voyage of the Henry Middleton to the Moluccas 1604-1606, London, Hakluyt Society.

Gauld, Richard A., and Michael B. Schiffer (ed.), 1981.Modern Material Culture: the Archaeo-logy of Us, New York:Acadeic Press.

Geert,Clifford.,1983.Local Knowledge, London, Fontana Press.

Gelpke, JHF Sollewijn.,1994. The Report of Miguel Roxo de Britto of his Voyage in 15811582 to the Raja Ampat, the MacCluer Gulf and Seram, Bijdragen tot de Taal-, Land-en Volkenkunde, deel 150, 1e Aflering, pp. 123-145
Hodder,lan., 1991.Reading the Past: Current Approaches to Interpretation in Archaeology, Cambridge, Cambridge University Press.

Kathirithamby-Wells, J.,1987.Forces of Regional and States Integration in the Western Archipelago c. 1500-1700, Joumal of Southeast Asian Studies, vol.XVIII (1), March, pp.2444

Knaap,Gerrit J.,1983. Some Observations on a Thriving Dancing-Party: The Cultivation of and the Competition for Clove in Sixteenth and Seventeenth Centuries Ambon, Papers of the Fourth Indonesian-Dutch History Conference, Yogyakarta.

.1993. The Saniri Tiga Air (Seram): an Account of its 'Discovery' and interpretation between about 1675-1950, Bijdragen tot de Taal-, Landen Volkenkunde, deel 149, $2 e$ Aflering, pp 250-273

Lewis,IM.1976.Social Anthropology in Perspective: the Relevance of Social Anthropology Cambridge:Cambridge University Press

Meilink-Roelofsz,M.A.P.,1962.Asian Trade and European Influence in the Indonesian Archipelago between 1500 and about 1630 The Hague, Martinus Nijhoff.

Nayati,Widya.,1994. The Archaeology of Trading Sites in the Indonesian Archipelago in the Sixteenth and Seventeenth Centuries:Possibilities and Limitations of the Evidence. Master Thesis Australian National University

Nayati,Widya., 1994.Perubahan-Perubahan Konsentrasi Perdagangan di Kepulauan $\mathrm{Nu}$ santara abad 16-17, Ceramah HIMA-UGM.

Nurhakim,Lukman,1989. La Ville de Barus: Etude Archaeologique Preliminarie, Archipel 37. pp. 43-52.

Pryor,Frederic L.,1977. The Origins of the Economy: a Comparative Study of Distribution in Primitive and Peasent Economies, New York, Academic Press

Reid, Anthony.,1992.Economis and Social Change, C 1400-1800, in Nicholas Tarling (ed.). The Cambridge History of Southeast Asia, Volume One, Cambridge:Cambridge University Press, pp. 460-507. 
Reid,Anthony, 1993. Southeast Asia in the Age of Commerce 1450-1680, Volume two: Expansian and Crisis, New Heaven:Yale University Press.

Sen, S.P.,1962.Indian Textile in South-East Asian Trade in the Seventeenth Century, Journal Southeast Asian History, vol. 3, no. 2 September, pp. 92-110 van Leur, J.C., 1955. Indonesian Trade and Society, The Hague, W. van Hoeve Ltd.

Wicks, Robert S. 1992. Money, Market, and Trade in Early Southeast Asia the Development of Indigenous Monetary System to AD 1400 New York:Southeast Asian Program 